\title{
Source, catabolism and role of the tetrapeptide N-Acetyl-Ser-Asp-Lys-Pro
}

\section{within the testis}

\author{
Jean-Philippe Stéphan ${ }^{1}$, Nathalie Melaine ${ }^{1}$, Eric Ézan ${ }^{2}$, Harri Hakovirta ${ }^{3}$, Simon Maddocks ${ }^{4}$, Jorma Toppari ${ }^{5}$, \\ Danielle-Hélène Garnier ${ }^{1}$, Joanna Wdzieczak-Bakala ${ }^{6}$ and Bernard Jégou ${ }^{1, *}$
}

${ }^{1}$ Groupe d'Etude de la Reproduction chez le Mâle (GERM), INSERM U-435, Université de Rennes I, Campus de Beaulieu, 35042 Rennes, Bretagne, France

${ }^{2}$ CEA, Service de Pharmacologie et d'Immunologie, CEA/Saclay, 91198 Gif-sur-Yvette, France

${ }^{3}$ Institute of Biomedicine, Department of Anatomy, University of Turku, FIN-20520 Turku, Finland

${ }^{4}$ Department of Animal Sciences, University of Adelaide, Waite Agricultural Research Institute, Glen Osmond, South Australia

5064, Australia

5Departement of Pediatrics and Physiology, University of Turku, FIN-20520, Turku, Finland

${ }^{6}$ Institut de Chimie des Substances Naturelles, CNRS, 91198 Gif-sur-Yvette, France

*Author for correspondence (e-mail: bernard.jegou@rennes-inserm.fr)

Accepted 18 October; published on WWW 9 December 1999

\section{SUMMARY}

The tetrapeptide N-Acetyl-Seryl-Aspartyl-Lysyl-Proline (AcSDKP) is a natural regulator of hematopoietic stem cell proliferation. The present study was aimed at investigating the presence and the role of AcSDKP in rat testis. Specific immunoreactivity was always observed in the interstitial tissue at all stages of testicular development and in elongated spermatids at $\mathbf{4 5}$ days of age and in adults. In accordance with the interstitial labeling, high AcSDKP levels were detected in Leydig cell and testicular macrophage culture media and cell extracts, as well as in the testicular interstitial fluid (TIF). Much lower concentrations were found in peritubular cells and Sertoli cells cultures, whereas very low concentrations were present in cultured spermatocytes and spermatids. In contrast to the slight degradation rate of AcSDKP observed in the spermatocyte and spermatid culture media, no catabolism of the peptide was seen in testicular somatic cell culture medium. Furthermore, the degradation rate of
AcSDKP was much lower in TIF than in peripheral blood plasma. Despite the very strong evidence indicating that Leydig cells and testicular macrophages produce AcSDKP, the selective destruction of these cells did not result in any change in AcSDKP levels in TIF or in plasma. This suggests a compensatory mechanism ensuring constant levels of the peptide in TIF when interstitial cells are absent. Finally, in vitro, in the presence of AcSDKP, significantly more $\left[{ }^{3} \mathbf{H}\right]$ thymidine incorporation was found in $\mathrm{A}$ spermatogonia. In conclusion, this study establishes the presence of very high concentrations of AcSDKP in rat testis and demonstrates its Leydig cell and testicular macrophage origin. The presence of AcSDKP in the TIF and its stimulatory effect on thymidine incorporation in spermatogonia very strongly suggest its implication in the paracrine control of spermatogenesis.

Key words: AcSDKP, Testis, Spermatogenesis, Stem cell

\section{INTRODUCTION}

The tetrapeptide N-Acetyl-Seryl-Aspartyl-Lysyl-Proline (AcSDKP; $487 \mathrm{Da})$, a physiological negative regulator of hematopoiesis, acts at $\mathrm{G}_{0} / \mathrm{G}_{1}$ or in early $\mathrm{G}_{1}$, thus blocking the transition from $\mathrm{G}_{0}$ to $\mathrm{S}$ phase of the hematopoietic stem cells (Monpezat and Frindel, 1989). It was originally purified from fetal calf bone marrow (Lenfant et al., 1989a) and eventually chemically synthesized (Lenfant et al., 1989b). In vivo, AcSDKP has been shown to prevent murine hematopoietic stem cells and early progenitors from entering into S-phase following administration of lethal doses of anti-cancer drugs (Lenfant et al., 1989a; Bogden et al., 1991; Aidoudi et al., 1996), or irradiation (Watanabe et al., 1996; Deeg et al., 1997). This confers to the tetrapeptide the ability to protect the hematopoietic stem cell compartment against cytotoxic agents and consequently the property to reduce mortality in mice (Bogden et al., 1991, 1998; Massé et al., 1998). It has also been reported to improve recovery from neutropenia in cancer patients simultaneously receiving AcSDKP and monochemotherapy with aracytine or ifosphamide (Carde et al., 1992). Recently, AcSDKP has been shown to be a physiological substrate for the $\mathrm{N}$-active site of angiotensin I converting enzyme (ACE) (Rousseau et al., 1995), suggesting a role for this enzyme in the regulation of hematopoiesis (Rousseau-Plasse et al., 1998).

In the testis, the sequence of events that results in the formation of mature spermatozoa from precursor cells is known as spermatogenesis and takes place within the seminiferous tubules (Jégou, 1993; Roosen-Runge, 1962). The 
stem cells for the spermatogenic process, the spermatogonia, undergo mitotic divisions. The spermatogenic process can be divided into three phases: the mitotic phase which includes spermatogonial renewal and proliferation, the meiotic phase, and spermiogenesis which corresponds to the metamorphosis of the haploid spermatids into spermatozoa. The seminiferous tubules are composed of Sertoli cells, whose interconnecting tight junctions constitute a key element of the blood-testis barrier (Ploën and Setchell, 1992), different categories of germ cells which progress between Sertoli cells from the basement membrane toward the tubule lumen, and peritubular cells which border the tubules and coproduce with the Sertoli cells the extracellular matrix of the lamina propria (Jégou, 1992; de Kretser and Kerr, 1994). Between the seminiferous tubules, the interstitial tissue encompasses the blood and lymphatic vessels, the testosterone-producing Leydig cells and the testicular macrophages that can represent up to $25 \%$ of the total cellular composition of this testicular compartment (Niemi et al., 1986). Both seminiferous tubules and interstitial cells are completely surrounded by the testicular interstitial space which contains the testicular interstitial fluid (TIF) (de Kretser and Kerr, 1994). Leydig cells secrete their products into this fluid and into the blood. Factors synthesized within the tubules, that locally modulate Leydig cell function, are also released into this fluid (Sharpe, 1993).

Spermatogenesis is under the control of the pituitary hormones FSH and LH, locally produced hormones such as testosterone, and also of a complex network of cellular interactions involving paracrine factors, which are thought to play a crucial role in the local control of germ cell proliferation and differentiation (Jégou, 1992, 1993; Sharpe, 1993). In spite of a number of studies on morphology and kinetic properties of male germ cell renewal and differentiation, very little is known about the regulation of spermatogonial cell proliferation and development in mammals. A few studies have suggested that several growth and differentiation factors inhibit or stimulate proliferation of spermatogonia. Of particular interest are the observations that two hematopoietic stem cell proliferation regulators, namely the stem cell factor (SCF) and the leukemia inhibitory factor (LIF) are able to regulate primordial germ cells and germ stem cell divisions (Donovan, 1994; Dym et al., 1995; Yoshinaga et al., 1991; Koshimizu et al., 1996). The reasons mentioned above have prompted us to investigate the presence, the cellular origin, the catabolism and the role of another hematopoietic regulator, AcSDKP, within rat testis.

\section{MATERIALS AND METHODS}

\section{Animals}

10-, 20- and 45-day-old and adult (more than 90-day-old) SpragueDawley male rats used for the different experiments were purchased from Elevage Janvier (Le Genest, Saint Isle, France).

\section{Peptide}

The tetrapeptide AcSDKP (purity $>95 \%$ ) was generously supplied by IPSEN-Biotech (Paris, France). The radiolabeled AcSD $4,4^{\prime}, 5,5^{\prime}$ $\left.{ }^{3} \mathrm{H}\right] \mathrm{KP}\left(\left[{ }^{3} \mathrm{H}\right]\right.$ AcSDKP $)$, specifically tritiated on the lysyl residue, was prepared, as previously described, with purity $>99 \%$ determined by radiochromatography HPLC (Sotty et al., 1991). The specific radioactivity was about $90 \mathrm{Ci} / \mathrm{mmol}(3247 \mathrm{Gbq} / \mathrm{mmol})$.

\section{Collection and preparation of biological fluids}

Testicular venous blood (TV) was collected from adult anaesthetized rats from a vein on the surface of the testis and spermatic venous blood (SV) collected from a vein in the spermatic cord above the pampiniform plexus (Maddocks et al., 1993). Animals were killed by decapitation and the peripheral blood $(\mathrm{P})$ was collected. All blood samples were collected in tubes containing heparin and centrifuged at $500 \mathrm{~g}$ for 15 minutes at $4^{\circ} \mathrm{C}$ to collect the plasma, which were frozen in liquid nitrogen. Immediately after blood collection, the testes were dissected out, washed with PBS buffer and incised at their caudal pole. Each testis was then suspended above a glass tube to allow the drainage of $50-100 \mu \mathrm{l}$ of TIF per testis at $4^{\circ} \mathrm{C}$, overnight. The TIF was then frozen in liquid nitrogen until use.

\section{Isolation and culture conditions of the different testicular cell types}

Leydig cells and testicular macrophages

Testicular macrophages and Leydig cells were isolated from testes of adult rats using centrifugal elutriation and Percoll gradient separation as previously described (Klinefelter et al., 1987) and slightly modified by us (Dejucq et al., 1998). The testicular macrophage fraction $(<1.068 \mathrm{~g} / \mathrm{ml})$ was cultured $\left(2 \times 10^{6}\right.$ cells $\left./ \mathrm{ml}\right)$ in Ham's F12/DMEM medium (1:1, v/v), supplemented with gentamycin $(50 \mu \mathrm{g} / \mathrm{ml}), 0.1 \%$ bovine albumin at $32^{\circ} \mathrm{C}$ in a humidified atmosphere of $5 \% \quad \mathrm{CO}_{2}-95 \%$ air. After washing of nonadherent cells, the degree of purity of isolated macrophages was $\geq 94 \%$ as visualized by esterase-positive staining, negative $3 \beta$ hydroxysteroid deshydrogenase ( $3 \beta$-HSD) staining and by immunocytochemistry using a macrophage specific monoclonal antibody (ED2). The Leydig cell fraction $(>1.068 \mathrm{~g} / \mathrm{ml}$ ) was resuspended $\left(1 \times 10^{6}\right.$ cells $\left./ \mathrm{ml}\right)$ and cultured in the same conditions as macrophages. The purity of the Leydig cell preparation, as determined by $3 \beta$-HSD histochemistry, was $\geq 93 \%$. After 24 hours of culture, the cells and their supernatants were separately recovered and frozen in liquid nitrogen until use.

\section{Sertoli cells}

Sertoli cells were prepared from 10-, 20- and 45-day-old rats, as described before (Skinner and Fritz, 1985) and cultured at $32^{\circ} \mathrm{C}$ in a humidified atmosphere of $5 \% \mathrm{CO}_{2}-95 \%$ air in Ham's F12/DMEM medium $(1: 1 \mathrm{v} / \mathrm{v})$, supplemented with gentamycin $(50 \mu \mathrm{g} / \mathrm{ml})$, insulin $(10 \mu \mathrm{g} / \mathrm{ml})$ and transferrin $(5 \mu \mathrm{g} / \mathrm{ml})$. On the third day of culture, the Sertoli cell monolayers were exposed to a hypotonic shock $(20 \mathrm{mM}$ Tris- $\mathrm{HCl}$ buffer solution, $\mathrm{pH}$ 7.4) for 2 minutes in the case of cells prepared from 10- and 20-day-old rats, and 15 minutes in the case of cells prepared from 45-day-old rats, to remove contaminating germ cells (Le Magueresse and Jégou, 1988). The degree of purity of the isolated Sertoli cells was $\geq 98 \%$. On day 4 of culture, the cells were incubated for 24 hours in fresh transferrin-free medium. At the end of incubation, media and cells were recovered and then frozen in liquid nitrogen until use.

\section{Peritubular cells}

The isolation of peritubular cells from 10-, 20- and 45-day-old rats was carried out during Sertoli cell preparation, as previously described (Skinner and Fritz, 1985). The cells were cultured in the same culture medium as described for Sertoli cells above, supplemented with $10 \%$ FCS. The degree of purity was $96 \%$ as assessed using an alkaline phosphatase histochemistry (Chapin et al., 1987). After 5-6 days of culture, the cells were removed by a brief treatment with trypsin $(1.7 \mathrm{mg} / \mathrm{ml})$, washed and then replaced at 0.25 density. When the subculture cells had grown to confluence, they were washed with PBS buffer and incubated with culture medium without FCS for 48 hours, with a change of medium after the first 24 hours. The cells and their supernatants were then collected and frozen separately in liquid nitrogen until use. 


\section{Germ cells}

Germ cells were prepared from adult rat testes by a trypsinisation procedure followed by centrifugal elutriation as described elsewhere (Pineau et al., 1991). Pachytene spermatocytes and early spermatids ( $\geq 90 \%$ pure as shown by DNA flow cytometry) were incubated for 24 hours at $32^{\circ} \mathrm{C}$, at a concentration of 2.5 and $8 \times 10^{6}$ cells $/ \mathrm{ml}$, respectively, in a PBS buffer supplemented with lactate $(6 \mathrm{mM})$, glucose $(5.6 \mathrm{mM})$, BSA $(0.4 \%)$ and gentamycin $(50 \mu \mathrm{g} / \mathrm{ml})$. At the end of this period, culture media and cells were centrifuged and frozen separately in liquid nitrogen until use.

\section{In vivo depletion of testicular macrophages}

One testis from each rat anaesthetized with ether was injected, using
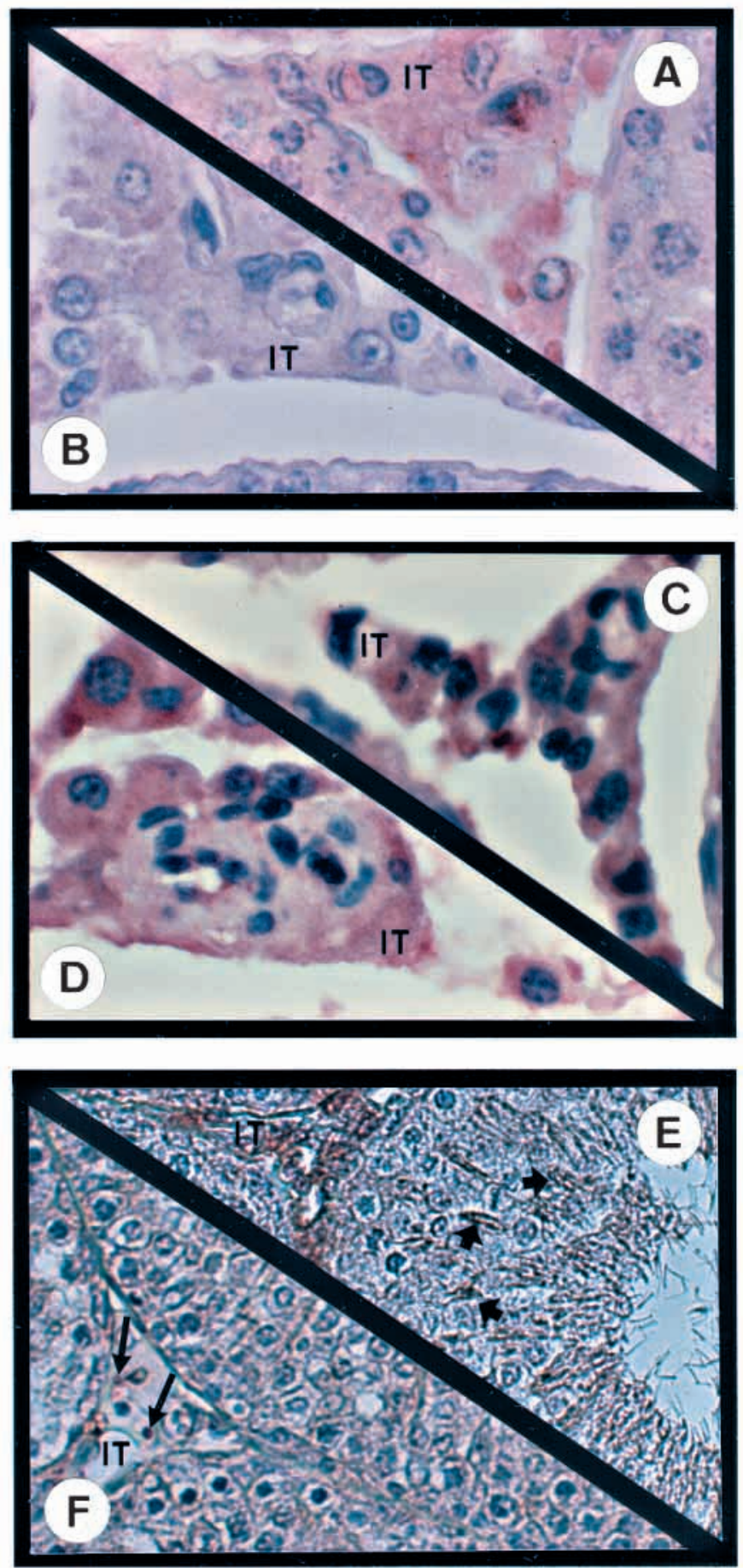

a 30.5 gauge needle, with $150 \mu \mathrm{l}$ of liposome entrapped PBS (control group) or liposome entrapped chlodronate, a macrophage toxin $\left(\mathrm{Cl}_{2} \mathrm{MDP}\right)$ (treated group), prepared as described and used elsewhere (Van Rooijen, 1989; Bergh et al., 1993). Fourteen days after treatment, all the animals were killed and their plasma collected. Their testes were dissected out, weighed and then used for collection of TIF, or prepared for immunohistochemical analysis. Neither the liposome entrapped PBS treatment nor the $\mathrm{Cl}_{2} \mathrm{MDP}$ treatment had any effect on the volume of TIF collected (data not shown).

\section{Depletion of Leydig cells}

Ethylene dimethane sulfonate (EDS), kindly provided by Dr Richard Sharpe (MRC, Edinburg, UK), a well known Leydig cell toxicant, was dissolved in dimethyl sulfoxide (DMSO):water (1:3, v/v), and administered in one intraperitoneal injection to adult rats $(75 \mathrm{mg} / \mathrm{kg})$ (Morris et al., 1986). Control animals were injected with vehicle alone. Eight days post-treatment, the rats were decapitated, blood was collected and plasma stored in liquid nitrogen until use. Testes were removed, weighed and used for collection of TIF or prepared for immunohistochemical analysis. The volume of TIF collected was reduced by an average of $36.5 \%$ after EDS treatment. Testosterone was assayed in plasma and TIF, according to a method described previously (Garnier et al., 1978). A double depletion of testicular macrophages and Leydig cells was also performed by injection with liposome entrapped chlodronate (intratesticular) and 6 days latter with EDS (intraperitoneal). Fourteen days after the first injection, testes were dissected out, weighed and used for collection of TIF, or prepared for immunohistochemical analysis.

\section{Microdissection of the tubule segments and assessment of germ cell $\left[{ }^{3} \mathrm{H}\right]$ thymidine incorporation}

Two- to 3-month-old Sprague-Dawley rats were used. Stages I, V, VIIa, VIII-IX, and XII of the seminiferous epithelial cycle were selected, since they contain representative phases of mitotic and meiotic DNA synthesis (Parvinen et al., 1991). During culture times of 48 and 72 hours, these stages differentiate through all stages of the cycle as follows: stage $\mathrm{I} \rightarrow \mathrm{I} \rightarrow \mathrm{III}-\mathrm{IV} \rightarrow \mathrm{V}$; stage $\mathrm{V} \rightarrow \mathrm{V} \rightarrow \mathrm{VI} \rightarrow \mathrm{VII}$; stage $\mathrm{VIIa} \rightarrow \mathrm{VIIb} \rightarrow \mathrm{VIIc} \rightarrow \mathrm{VIII}$; stage VIII-IX $\rightarrow \mathrm{IX} \rightarrow \mathrm{XI} \rightarrow \mathrm{XII}$; stage $\mathrm{XII} \rightarrow \mathrm{XIV} \rightarrow \mathrm{I} \rightarrow \mathrm{I}$, respectively. Tubule segments $(2 \mathrm{~mm})$ were isolated under a transilluminating stereomicroscope for in vitro analyses of $\left[{ }^{3} \mathrm{H}\right]$ thymidine incorporation. Stages were identified by specific transillumination pattern (Parvinen and Vanha-Perttula, 1972). Staged tubule segments were transferred onto 96-well culture plates in $10 \mu \mathrm{l}$ of PBS and incubated at $34^{\circ} \mathrm{C}$ for 48 and 72 hours as previously

Fig. 1. Immunolocalization of AcSDKP in rat testis. All testes used in these studies were fixed in Bouin's solution and immunolocalization of AcSDKP was performed using a rabbit polyclonal AcSDKP anti-serum and an avidin-biotin-peroxydase complex amplification combination. (A) In adult rat testis, strong immunoreactivity was observed within the interstitial tissue (IT). (B) Immunoreactivity was abolished when AcSDKP anti-serum was pre-absorbed with the purified tetrapeptide. Section from rat testes injected with PBS (C) or $\mathrm{Cl}_{2} \mathrm{MDP}$-containing liposomes (D) 14 days earlier, were incubated with the polyclonal AcSDKP anti-serum. Note that strong AcSDKP labeling was still present in the interstitium of the macrophage-depleted testes (IT, D vs C for control). Testis sections from PBS (E) or EDS-treated (F) rats were incubated with the polyclonal AcSDKP anti-serum. The AcSDKP labeling present in the interstitium of the control (PBS) animals (IT, E) was decreased in the interstitium of the EDS-treated rats due to Leydig cell disappearance (F). However, a few AcSDKP positive interstitial cells, probably corresponding to macrophages, were still visible in the testis of these rats (F, small arrows). In the seminiferous epithelium, elongated spermatids (arrows) were labeled. Magnification: $\times 220(\mathrm{~A}, \mathrm{~B}, \mathrm{C}, \mathrm{D}) ; \times 110(\mathrm{E}$ and F). 


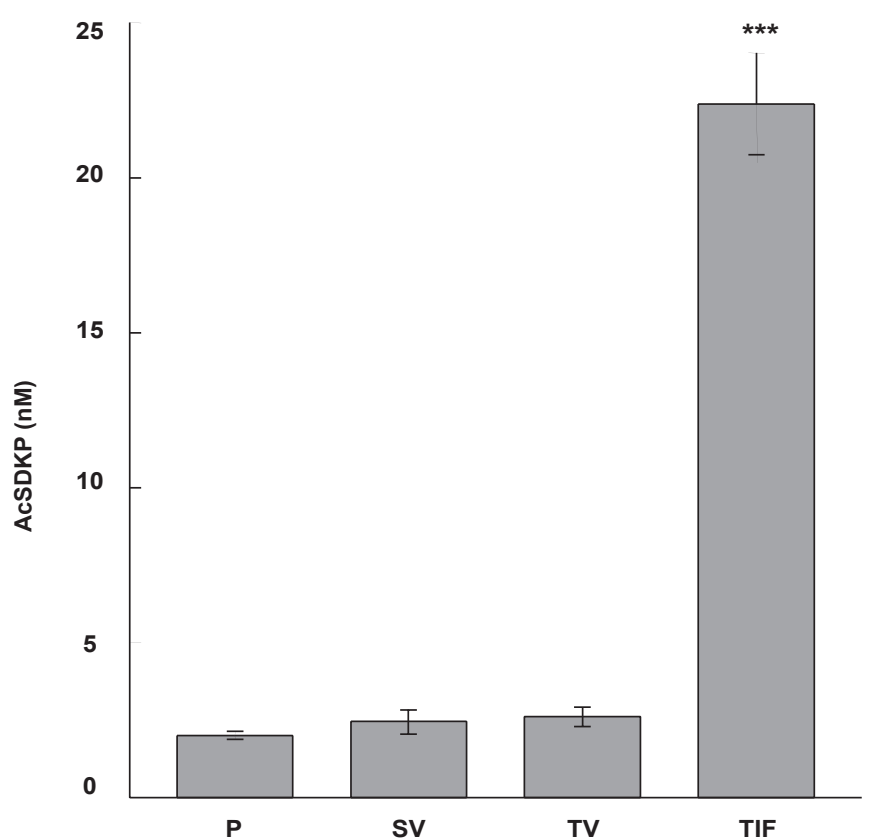

Fig. 2. AcSDKP levels in testicular interstitial fluid (TIF) and in plasma prepared from peripheral $(\mathrm{P})$, spermatic venous $(\mathrm{SV})$ and testicular venous (TV) blood collected in adult male rats. P, SV and PV were collected from 5 animals whereas TIF was prepared by gravitation from 27 testes. AcSDKP concentration was determined by a highly specific EIA. Values are the mean \pm s.e.m. $* * * P<0.001$, as compared to AcSDKP concentrations in the plasma prepared from peripheral blood.

described (Hakovirta et al., 1995). AcSDKP was added at concentrations of $0,100 \mathrm{ng} / \mathrm{ml}$ and $1 \mu \mathrm{g} / \mathrm{ml}$. During the last 4 hours of culture, tubules were pulse-labeled by adding $20 \mathrm{kBq}$ of [methyl$\left.{ }^{3} \mathrm{H}\right]$ thymidine (TRA 120, $185 \mathrm{Gbq} / \mathrm{mmol}$, Amersham, UK) and harvested on filter discs (Whatman 934-AH) with continuous flow of distilled water for one minute. Scintillation wax (MeltiLexTMA 1450441, Wallac, Turku, Finland) was melted on the filters and radioactivity was assayed by a flat bed scintillation counter (1450 Microbeta, Wallac, Turku, Finland). Three separate experiments for each timepoint were assayed with 4 replicate samples. For autoradiographic analyses, labeled tubule segments were carefully squashed between microscope slides and coverslips and frozen in liquid nitrogen (Toppari and Parvinen, 1985). The coverslips were removed and still frozen preparations fixed in ethanol-glacial acetic acid $(3: 1, v / v)$ for 30 minutes and air dried. The slides were dipped in Kodak NTB-3 nuclear track emulsion (Eastman Kodak Co., Rochester, NY), exposed for 2 days, developed and stained with haematoxylin.

\section{AcSDKP assay}

AcSDKP levels in rat plasma, TIF, cell culture media and cell lysates were determined by a highly specific competitive enzyme immunoassay (EIA) (Pradelles et al., 1990). The limit of quantification of this assay was $0.5 \mathrm{pmol} / \mathrm{ml}$ and the precision was characterized by a variation coefficient of less than $20 \%$ in the $1-10$ $\mathrm{nM}$ range. The results were expressed as $\mathrm{nM} \pm$ s.e.m. for biological fluids or pmoles \pm s.e.m. of AcSDKP per $\mathrm{mg}$ of protein for the different cell types.

\section{AcSDKP catabolism}

The kinetics of AcSDKP degradation was determined in plasma, TIF and in the different testicular cell supernatants. Briefly, $500 \mu \mathrm{l}$ of each

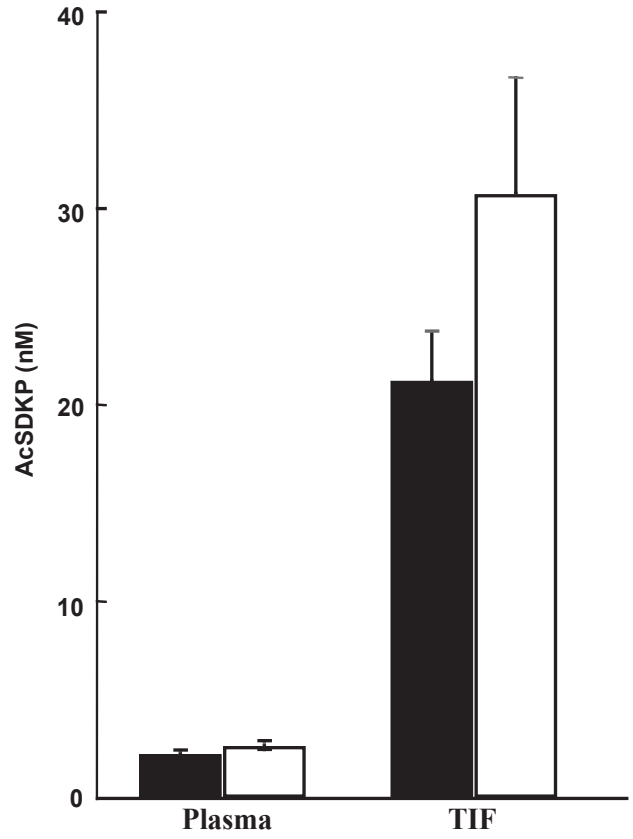

Fig. 3. Effect of the selective depletion of testicular macrophages on AcSDKP levels in plasma and TIF. Plasma was prepared from peripheral blood collected from adult rats injected intratesticulary with liposome-entrapped PBS ( $\mathbf{\square})$ (control, $n=16$ ) or liposomeentrapped $\mathrm{Cl}_{2} \mathrm{MDP}(\square)$ (treated, $n=16$ ), and TIF was collected from testes injected with liposomes-entrapped PBS ( $\square$ ) or $\mathrm{Cl}_{2} \mathrm{MDP}(\square)$ from the same animals. AcSDKP was measured using a specific EIA. Each histogram value represents the mean \pm s.e.m.

preparation were incubated with $15 \mu \mathrm{l}$ of $\left[{ }^{3} \mathrm{H}\right] \mathrm{AcSDKP}$ solution (final concentration $\left.4 \times 10^{-7} \mathrm{M}\right)$ at $37^{\circ} \mathrm{C}$. At different periods of time $(0-8$ hours), $30 \mu \mathrm{l}$ aliquots were drawn, supplemented with $10 \mu \mathrm{l}$ of carrier mixture of AcSDKP, Lys-Pro and Lys $(2 \mathrm{mg} / \mathrm{ml})$ and immediately frozen on dry ice. All samples were then analysed in duplicate by high-voltage electrophoresis and scintillation counting, as previously described (Rieger et al., 1993). The values of radioactivity specifically associated with AcSDKP and its degradation products were used to determine the kinetics of AcSDKP hydrolysis and to calculate its mean half-life time $\left(\mathrm{t}_{1 / 2}\right)$ in the analysed biological fluids.

\section{AcSDKP and ED2 immunolocalization}

Testes from normal 10, 20, 45-days-old and adult rats testes, as well as from adult rats whose testes had been depleted of macrophages or Leydig cells were carefully dissected out, fixed in Bouin's solution and dehydrated through increasing grades of alcohol, before being embedded in paraffin wax. Sections $(4 \mu \mathrm{m})$ were incubated with a rabbit polyclonal AcSDKP anti-serum (Pradelles et al., 1990), with a working dilution of 1:1000, using an avidin-biotin-peroxidase complex amplification combination. Sections from macrophagedepleted adult rat testes were also incubated with a monoclonal antibody (ED2) recognizing testicular rat macrophages, in order to verify the total depletion of the testicular macrophages after the liposome entrapped $\mathrm{Cl}_{2} \mathrm{MDP}$ treatment (Bergh et al., 1993). For both AcSDKP and ED2 immunolocalisation experiments, PBS and normal serum and/or immuno-absorbed antibodies were used as negative controls.

\section{Statistical analysis}

Results are expressed as means \pm s.e.m. Differences in mean were compared using an unpaired two-tailed Student's $t$-test. Differences were considered significant if $P<0.05$. 
A

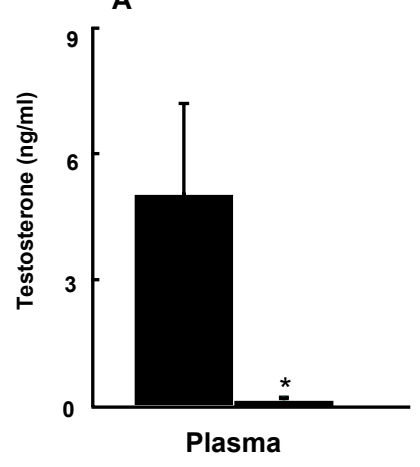

C

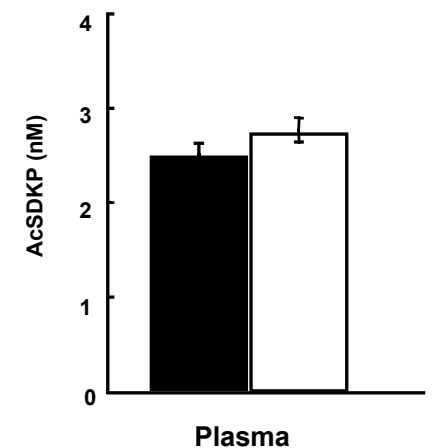

B
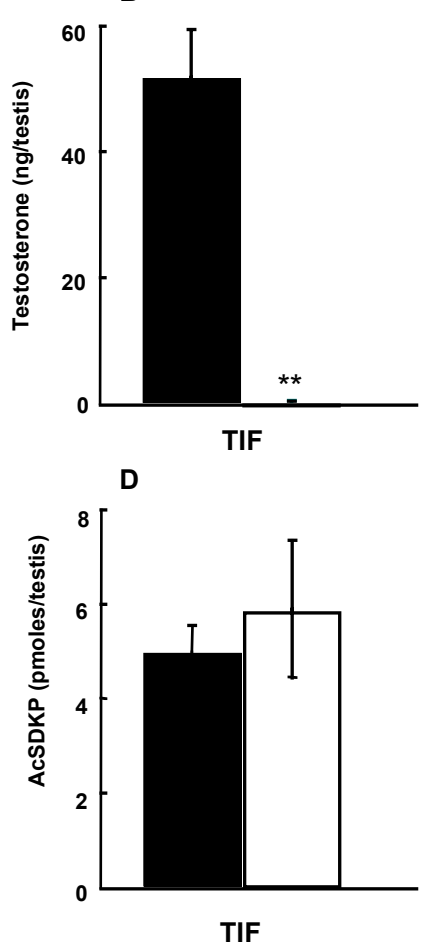

Fig. 4. Effect of the selective depletion of Leydig cells on testosterone and AcSDKP levels in peripheral plasma and TIF. Plasma $(\mathrm{A}, \mathrm{C})$ and TIF $(\mathrm{B}, \mathrm{D})$ were collected from PBS $(\mathbf{\square})(n=10)$ and EDS $(\square)(n=10)$ treated animals. Testosterone $(\mathrm{A}, \mathrm{B})$ and $\operatorname{AcSDKP}(\mathrm{C}, \mathrm{D})$, were assayed using a RIA and an EIA procedure respectively, as described in the Materials and Methods section. Values are the mean \pm s.e.m. $(* P<0.05, * * P<0.01)$.

\section{RESULTS}

\section{Immunodetection and fluid concentrations of AcSDKP in the rat}

In testes from adult rats (Fig. 1A,C and E) and from immature, prepubertal and pubertal rats (10, 20 and 45 days, respectively; data not shown) a strong immunoreactivity was observed within the interstitial tissue. A weaker staining was consistently detected in elongated spermatids (Fig. 1E).

Table 1. Degradation of $\left[{ }^{3} \mathrm{H}\right]$ AcSDKP in the culture media of different testicular cell types

\begin{tabular}{lc}
\hline Cell types & $\begin{array}{c}\text { \% of intact }\left[{ }^{3} \mathrm{H}\right] \text { AcSDKP } \\
\text { after } 6 \text { hours of incubation }\end{array}$ \\
\hline Leydig cells & $98.83 \pm 0.98$ \\
Macrophages & $99.4 \pm 0.6$ \\
Peritubular cells & 100 \\
Sertoli cells & 100 \\
Pachytene spermatocytes & $87.0 \pm 7.8$ \\
Early spermatids & $90.7 \pm 5.1$
\end{tabular}

$\left[{ }^{3} \mathrm{H}\right] \mathrm{AcSDKP}$ was incubated for 6 hours in the presence of $500 \mu \mathrm{l}$ of conditioned media of Leydig cells, testicular macrophages and germ cells prepared from testis of 90 -day-old rats and $500 \mu \mathrm{l}$ of conditioned media collected from peritubular cells and Sertoli cells prepared from 10-, 20- and 45-day-old rats. Residual $\left[{ }^{3} \mathrm{H}\right]$ AcSDKP was quantified by electrophoresis and the associated radioactivity was determined. Values are mean \pm s.e.m. for at least 3 independent experiments each performed in duplicate.

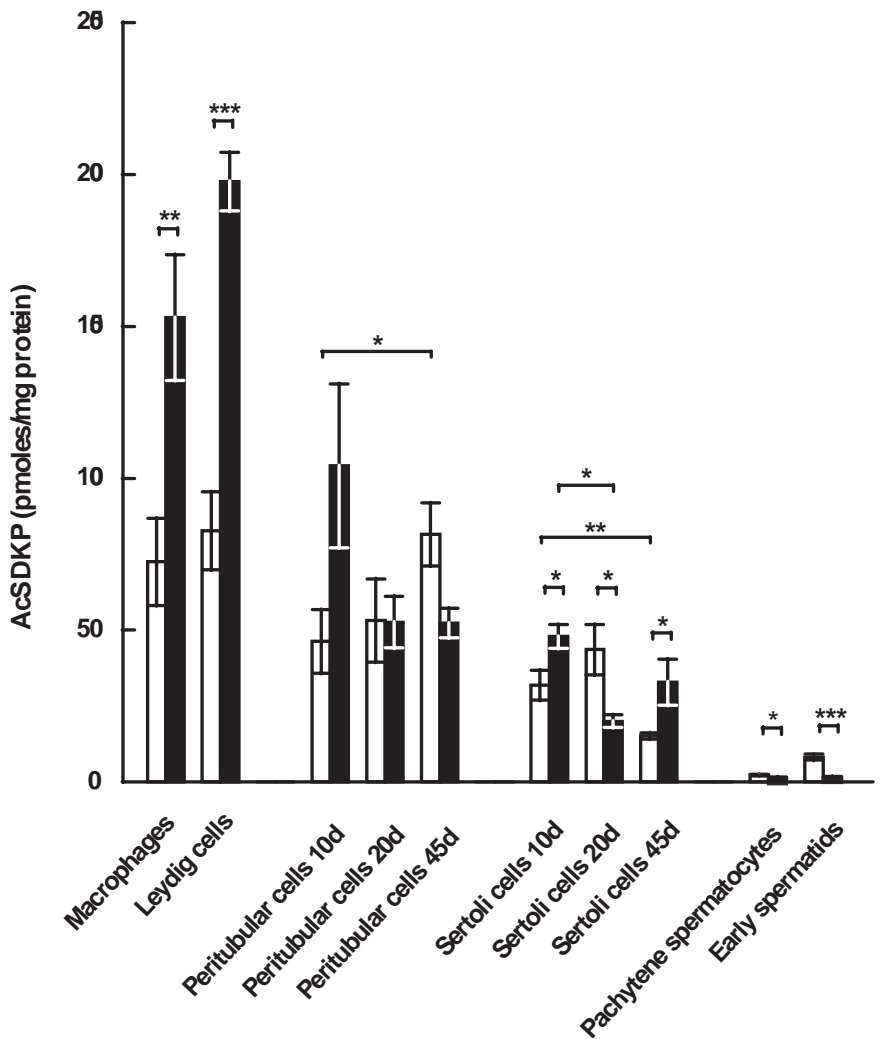

Fig. 5. AcSDKP levels in culture media and extracts of different isolated testicular cell types. Due to the low number of purified cells collected, macrophages and Leydig cells were prepared only from adult rats (90 days), while Sertoli cells and peritubular cells were collected from immature $(10$ days $=10 \mathrm{~d})$, prepubertal $(20$ days $=20$ d) and pubertal $(45$ days $=45 \mathrm{~d})$ rats. The cells were cultured in appropriate medium during various periods of time (see Material and Methods section). The cells were scraped for preparation of extracts and 24 hours incubation media collected. AcSDKP was measured in cell extracts $(\square)$ and culture media ( $\square$ ) by an EIA. Each histogram value represents the mean \pm s.e.m. of at least 3 independent experiments each performed in duplicate $(* P<0.05$; $* * P<0.01$; $* * * P<0.001)$, as compared to conditions indicated by the brackets.

Immunoreactivity was abolished when the AcSDKP antiserum was replaced by normal rabbit serum or by a neutralized AcSDKP anti-serum (Fig. 1B).

As AcSDKP was principally detected in the interstitial compartment which contained both lymphatic and blood vessels, we then investigated its possible presence in the testicular interstitial fluid (TIF). We observed very high levels of AcSDKP in the TIF as compared to the peripheral blood plasma (Fig. 2). The peptide concentrations measured in the testicular venous blood and in the spermatic venous blood did not differ from those found in the peripheral blood (Fig. 2).

\section{Immunodetection and fluid concentrations of AcSDKP in testicular macrophage- and Leydig cell- depleted rats}

In order to investigate the contribution of macrophages to the immunoreactivity detected in situ in the interstitium and to the levels of AcSDKP in plasma and in testicular interstitial fluid (TIF), the effects of macrophage depletion were investigated. 


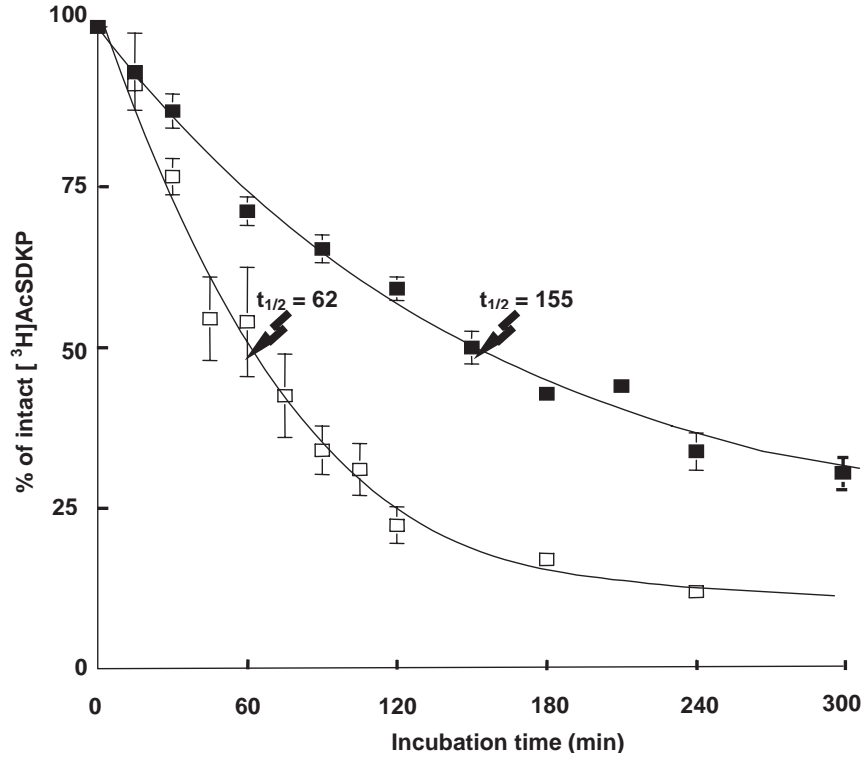

Fig. 6. Kinetics of AcSDKP catabolism in plasma and TIF of adult rat. $\left[{ }^{3} \mathrm{H}\right] \mathrm{AcSDKP}$ was incubated for various periods of time in $500 \mu \mathrm{l}$ of plasma $(\square)$ or of TIF $(\boldsymbol{\square})$. Residual $\left[{ }^{3} \mathrm{H}\right]$ AcSDKP was quantified by electrophoresis and measurement of the associated radioactivity. Values are the mean \pm s.e.m. for 3 independent experiments each performed in duplicate.

The use of an antibody (ED2) which recognizes macrophages confirmed that administration of liposome entrapped $\mathrm{Cl}_{2} \mathrm{MDP}$ resulted in the selective destruction of testicular macrophages (data not shown). In these testes, strong AcSDKP immunolabeling was still observed within the interstitial compartment corresponding to the Leydig cells labeling (Fig. 1C vs D). In accordance with these results, AcSDKP plasma and TIF levels were not significantly affected by testicular macrophage depletion (Fig. 3).

The possible effect of the removal of Leydig cells was also investigated using EDS, a drug that causes selective Leydig cell destruction. Eight days after treatment with EDS, Leydig cells were absent in the interstitial tissue and the most prevalent cell type in the interstitial space was the macrophages. In this context, the AcSDKP immunolabeling in the interstitium was dramatically reduced (Fig. 1E vs F), and testosterone levels in both blood plasma (Fig. 4A) and TIF (Fig. 4B) were reduced by 96 and $99 \%$, respectively. In spite of the destruction of the Leydig cells in the EDS-treated rats, the AcSDKP concentrations were unaltered in the peripheral plasma (Fig. 4C), as well as in TIF (Fig. 4D). Similar results were also observed when testicular macrophages and Leydig cells were simultaneously depleted (data not shown).

\section{AcSDKP levels in culture media and extracts of different isolated testicular cell types}

To investigate further the cellular source of AcSDKP within the testis, the peptide levels were determined in the culture media and cell extracts from Leydig cells, testicular macrophages, peritubular cells, Sertoli cells and germ cells (Fig. 5). The highest concentrations of AcSDKP were detected within Leydig cells and testicular macrophages. AcSDKP levels detected in the conditioned media from these cells was

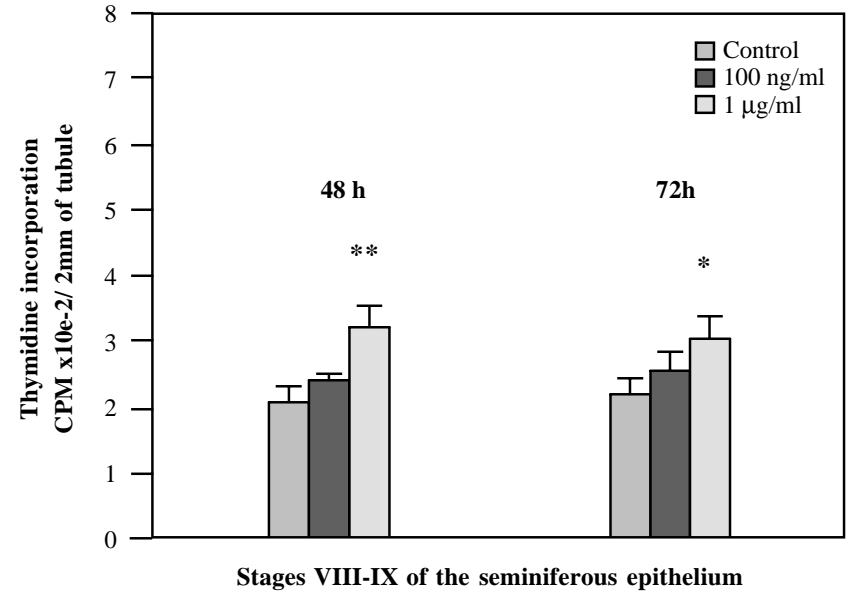

Fig. 7. Effects of AcSDKP on germ cells $\left[{ }^{3} \mathrm{H}\right]$ thymidine incorporation. The $\left[{ }^{3} \mathrm{H}\right]$ thymidine incorporation (counts per minute (cpm), mean \pm s.e.m., $n=12$, normalized to $2 \mathrm{~mm}$ of tubule) at stages I, V, VIIa, VIII-IX, XII of the seminiferous epithelium cultured for 48 and 72 hours with $0,100 \mathrm{ng} / \mathrm{ml}\left(2.10^{-7} \mathrm{M}\right)$ or $1 \mu \mathrm{g} / \mathrm{ml}\left(2 \times 10^{-6} \mathrm{M}\right)$ of AcSDKP. At 48 and 72 hours, the highest concentration of AcSDKP stimulated tubule segments from stages VIII-IX of the cycle significantly $(P<0.01$ and $P<0.05$, respectively). Progression of the tubule segments at given timepoints are described in Materials and Methods. As no effect of AcSDKP on thymidine incorporation was seen in tubule segments other than those at stages VIII-IX, the corresponding histograms are not presented. $* P<0.05$ and $* * P<0.01$.

about twice the intracellular levels. The peptide also appeared to be present in peritubular cells, though at lower concentrations than in the interstitial cells. Furthermore, no significant difference was seen between AcSDKP levels determined in extra- and intracellular fractions of peritubular cells levels prepared from 10- and 20-day-old rats, whereas the intracellular levels of the peptide were slightly higher within the cells from 45-day-old animals. The concentration of AcSDKP was low in Sertoli cells, and the peptide levels were higher in the conditioned media of cells obtained from 10- and 45-day-old rats, whereas the reverse situation was seen for Sertoli cells from 20-day-old animals. Very low levels of AcSDKP were seen in germ cells, which consistently display higher intracellular concentrations, when compared to the concentrations observed in the media.

\section{Stability of AcSDKP in testicular culture media, TIF and plasma}

In order to study the possible degradation of AcSDKP in the culture media of the different testicular cell types studied, we incubated $\left[{ }^{3} \mathrm{H}\right] \mathrm{AcSDKP}$, for 6 hours, in media collected from cultures of the different testicular cell types. Table 1 shows that a slight degradation of $\left[{ }^{3} \mathrm{H}\right] \mathrm{AcSDKP}$ (about $10 \%$ ) occurred in germ cell culture media whereas, in contrast, no degradation of the peptide was observed in the media of peritubular cells, Sertoli cells, testicular macrophages or Leydig cells. In the peripheral blood plasma, more than $85 \%$ of $\left[{ }^{3} \mathrm{H}\right]$ AcSDKP was degraded after 4 hours of incubation and the apparent half-life $\left(t_{1 / 2}\right)$ of the peptide was 62 minutes (Fig. 6). The catabolism of AcSDKP in the TIF was much slower, with $\mathrm{t}_{1 / 2}$ of 155 minutes (Fig. 6). 


\section{Effects of AcSDKP on $\left[{ }^{3} \mathrm{H}\right]$ thymidine-labeled germ cells}

To assess the possible role of AcSDKP in germ cell regulation, microdissected seminiferous tubules from stages I, V, VIIa, VIII-IX and XII were cultured for 48 and 72 hours in the presence of an increasing concentration of peptide. During culture, these tubule segment progress through the rest of the cycle (Hakovirta et al., 1995; see Materials and Methods). When cultured in the presence of $1 \mu \mathrm{g} / \mathrm{ml}$ of AcSDKP for 48 and 72 hours, tubule segments from stages VIII-IX of the cycle consistently showed significantly increased incorporation of $\left[{ }^{3} \mathrm{H}\right]$ thymidine $(P<0.01$ and $P<0.05$, respectively) (Fig. 7). This was further confirmed by autographic quantification showing that there was an increased number of labeled spermatogonia $(P<0.05)$ in the tubule segments from stages VIII-IX of epithelium when cultured in the presence of $1 \mu \mathrm{g} / \mathrm{ml}$ of AcSDKP (not shown).

\section{DISCUSSION}

The tetrapeptide AcSDKP, initially purified from fetal calf bone marrow, is a negative physiological regulator of the hematopoietic stem cell entry into the cell cycle (Lenfant et al., 1989a). In the present study, we demonstrate AcSDKP immunoreactivity in testis from adult as well as from 10-, 20and 45-day-old rats (not shown). By far, strongest and most consistent immunoreactivity was observed in the interstitial tissue. This result was confirmed by the localization of AcSDKP immunoreactivity in isolated Leydig cells and testicular macrophages (not shown). In addition, the fact that high concentrations of AcSDKP were found in Leydig cells and testicular macrophages, as well as in the conditioned media from these two interstitial cell types, strongly supports the hypothesis that these cells are the essential sources of AcSDKP within the normal testis. Production of AcSDKP by the testicular macrophages is in line with previous results suggesting the synthesis and release of this peptide by macrophages, in long-term bone marrow culture ( $\mathrm{Li}$ et al., 1997).

A consistent and significant labeling was observed in elongated spermatids. However, as the cells cannot be isolated intact, late spermatid production of AcSDKP could not be ascertained. In contrast, our results show that AcSDKP could also be detected in isolated peritubular cells and Sertoli cells at all ages, whereas in some experiments a weak labeling could be observed in these cells. However, the observation and the release of the tetrapeptide in the culture media being not consistent, the question whether Sertoli cells and peritubular cells synthesize AcSDKP or concentrate the peptide produced in the interstitial compartment remains to be clarified.

Lack of AcSDKP immunoreactivity in pachytene spermatocytes and early spermatids from adult testis is compatible with the extremely low levels of peptide detected in both the conditioned media and cell extracts from these cells. Of note is that a low catabolism of the peptide was evidenced in the germ cell conditioned media. It is well documented that AcSDKP hydrolysis is under the control of the angiotensin Iconverting enzyme (ACE; Rieger et al., 1993; Rousseau et al., 1995). As a specific germinal isoform of the ACE has been detected in spermatids (Sibony et al., 1994; Williams et al.,
1995), it is possible that the low AcSDKP catabolism consistently observed in the spermatid conditioned media results from the release of ACE by the cells during incubation. However, the origin of the catabolism seen in pachytene spermatocyte media remains unknown.

The concentrations of AcSDKP measured in the TIF were much higher than those found in the testicular or peripheral blood of the rat and corresponded to the highest levels of AcSDKP so far detected in a biological fluid. This could results from accumulation of AcSDKP entering the testis from blood. However, we demonstrate that the catabolism of AcSDKP is much lower in the TIF than in the blood. Therefore, this could, at least in part, explain the difference in the peptide concentrations measured in these two fluids. It is quite possible that this slow catabolism and the resulting high concentrations of AcSDKP in TIF are the consequence of the fact that the specific testis isoform of ACE lacks the N-terminal domain of the somatic ACE (Ehlers and Kirsch, 1988) that preferentially degrades AcSDKP (Rousseau et al., 1995). The presence of very high levels of AcSDKP in the TIF is also consistent with the high production rate of this tetrapeptide by Leydig cells and testicular macrophages, in vitro. However, we demonstrate that, in the absence of Leydig cells in EDS-treated animals or of testicular macrophages following in vivo treatment with liposome-entrapped $\mathrm{Cl}_{2} \mathrm{MDP}$ in vivo treatment, AcSDKP levels in the interstitial fluid remain unchanged. Similarly, in absence of both interstitial cells, no variation of TIF AcSDKP levels was observed. It could be that when one of the two major categories of interstitial cells (Leydig cells or testicular macrophages) is absent, AcSDKP production by other testicular cells occurs or increases, thus allowing the maintenance of a constant TIF AcSDKP concentrations. In this situation, Sertoli cells or peritubular cells may be responsible for the maintenance of AcSDKP TIF concentrations. Such compensatory production mechanism has recently been demonstrated in the case of the macrophage-migration inhibitory factor, after EDS-induced Leydig cell ablation in the rat (Meinhardt et al., 1998). However, as in our experiments, in the absence of both Leydig cells and macrophages, no immunostaining appeared in the remaining testicular cells, it could also be that in Leydig cell and testicular macrophagedepleted rats modifications of AcSDKP testicular metabolism occur and/or that depletion in the cellular contents of the interstitium modifies the dynamics of TIF production (the volume of TIF collected in EDS treated rats was reduced by $36.5 \%$ ), thus resulting in accumulation of AcSDKP.

Considering the presence of very high concentrations of AcSDKP within the interstitium in the vicinity of spermatogonia, and the known role of this peptide as a regulator of hematopoietic stem cell proliferation, it is tempting to speculate that this peptide may also be involved in the control of germ stem cell proliferation. In fact, our results showing that A spermatogonial thymidine incorporation was consistently and significantly increased in the presence of AcSDKP, together with the fact that spermatogonia undergo a fixed number of prescheduled mitoses during their differentiation, strongly suggests that, AcSDKP promotes spermatogonia survival. This role in spermatogenesis is clearly different to the role of AcSDKP as a negative regulator of hematopoïesis. The presence of this peptide in elongated spermatids may also be indicative that this peptide plays a role 
yet to be elucidated in the regulation of other steps of spermatogenesis. Morever, whether other testicular cell types such as Sertoli cells or peritubular cells represent targets for AcSDKP remains unclear. This possibility cannot be excluded since in the hematopoietic system, AcSDKP was shown to affect not only the stem cells, but also stromal bone marrow cells (Lenfant et al., 1989b; Hong et al., 1995).

We are grateful to Dr R. Genet (CEA, Saclay, France) for providing us with the tritiated AcSDKP. We are also indebted to BOEHRINGER MANNHEIM GMBH (Mannheim, Germany) for the gift of $\mathrm{Cl}_{2} \mathrm{MDP}$, to Ms S. Michelet, Ms N. Cheviron, Mrs A.M. Touzalin and Mr A. Le Nedic for their excellent technical assistance. We thank Dr E. Deschamps de Paillette for her assistance and encouragement. This work was supported by INSERM, CNRS, DRED, Region Bretagne, Fondation Langlois, IPSEN-Biotech and Grant program ACC-SV from the Ministère de l'Enseignement Supérieur et de la Recherche.

\section{REFERENCES}

Aidoudi, S., Guignon, M., Leuberier, M., Caen, J., and Han, Z. C. (1996) In vivo effect of the platelet factor 4 (PF4) and the tetrapeptide AcSDKP on haematopoiesis of mice treated with 5-fluorouracil. Br. J. Hematol. 94, 443448.

Bergh A., Damber, J. E., and van Rooijen N. (1993). Liposome-mediated macrophage depletion: an experimental approach to study the role of testicular macrophages in the rat. J. Endocrinol. 136, 407-413.

Bogden A. E., Carde, P., Deschamps de Paillette, E., Moreau, J. P., Tubiana, M., and Frindel, E. (1991). Amelioration of chemotherapyinduced toxicity by cotreatment with AcSDKP, a tetrapeptide inhibitor of hematopoietic stem cell proliferation. Ann. NY Acad. Sci. 628, 126139.

Bogden, A. E., Moreau, J. P., Gamba-Vitalo, C., Deschamps de Paillette, E., Tubiana, M., Frindel, E., and Carde, P. (1998). Goralatide (AcSDKP), a negative growth regulator, protects the stem cell compartment during chemotherapy, enhancing the myelopoietic response to GM-CSF. Int. J. Cancer 76, 38-46

Carde, P., Chastang, C., Goncalves, E., Mathieu-Tubiana, N., Vuillemin, E., Delwail, V., Corbion, O., Vekhoff, A., Isnard, F., Ferrero, J. M., et al. (1992). Seraspenide (AcetylSDKP): phase I-II trial study of inhibitor of hematopoiesis protects against toxicity of aracytine and ifosfamide monochemotherapies. CR Acad. Sci. III 315, 545-550

Chapin, R. E.,. Phelps, J. L, Miller, B. E, and. Gray, T. J. (1987). Alkaline phosphatase histochemistry discriminates peritubular cells in primary rat testicular cell culture. J. Androl. 8, 155-161.

Deeg, H. J., Seidel, K., Hong, D. S, Yu, C., Huss, R., Schuening, F. G, Ewel, C. H., and Storb, R. (1997). In vivo radioprotective effect of AcSDKP on canine myelopoiesis. Ann. Hematol. 74, 117-122.

Dejucq, N., Lienard, M. O., Guillaume, E., Dorval, I., and Jégou, B. (1998). Expression of interferon- $\alpha$ and $-\gamma$ in testicular interstitial tissue and spermatogonia of the rat. Endocrinology 139, 3081-3087

de Kretser, D. M. and Kerr, J. B. (1994). The cytology of the testis. In The Physiology of Reproduction (ed E. Knobil, and J. D. Neil), pp. 1177-1290. New York: Raven Press Ltd.

Donovan, P. J. (1994). Growth factor regulation of mouse primordial germ cell development. Curr. Top. Dev. Biol. 29, 189-225.

Dym, M., Jia, M. C., Dirami, G., Price, J. M., Rabin, S. J., Mocchetti, I. and Ravindranath, N. (1995). Expression of c-kit receptor and its autophosphorylation in immature rat type A spermatogonia. Biol. Reprod. 52, 8-19.

Ehlers, M. R. and Kirsch, R. E. (1988). Catalysis of angiotensine I hydrolysis by human angiotensin-converting enzyme: effect of chloride and $\mathrm{pH}$. Biochemistry 27, 5538-5544.

Garnier, D. H., Cotta, Y. and Terqui, M. (1978). Androgen radioimmunoassay in the rat: results of direct plasma testosterone and dehydroepiandrosterone measurement and physiological evaluation. Ann. Biol. Anim. 18, 265-281.

Hakovirta, H., Syed, V., Jégou, B. and Parvinen M. (1995). Function of the interleukin-6 as an inhibitor of meiotic DNA synthesis in the rat seminiferous epithelium. Mol. Cell. Endocrinol. 108, 193-198.
Hong, D. S., Graham, T., Ewel, C., Storb, R. and Deeg, H. J. (1995). Inhibition of hematopoiesis in long-term marrow cultures established on adherent layer from AcSDKP treated dogs. Exp. Hematol. 23, 639-644.

Jégou, B. (1992). The Sertoli cell. In The Testis. Bailliéres Clinical Endocrinology and Metabolism (ed D. M. de Kretser), pp. 273-311.

Jégou, B. (1993). The Sertoli-germ cell communication network in mammals. Int. Rev. Cytol. 147, 25-96.

Klinefelter, G. R., Hall, P. F. and Ewing L. L. (1987). Effect of luteinizing hormone deprivation in situ on steroidogenesis of rat Leydig cells purified by a multistep procedure. Biol. Reprod. 36, 769-783.

Koshimizu, U., Taga, T., Watanabe, M., Saito, M., Shirayoshi, Y., Kishimoto, T. and Nakatsuji, N. (1996). Functional requirement of gp130mediated signaling for growth and survival of mouse primordial germ cells in vitro and derivation of embryonnic germ (EG) cells. Development $\mathbf{1 2 2}$, 1235-1242.

Le Magueresse, B. and Jégou, B. (1988). In vitro effects of germ cells on the secretory activity of Sertoli cells recovered from rats of differents ages. Endocrinology 122, 1672-1680.

Lenfant, M., Wdzieczak-Bakala, J., Guittet, E., Prome, J. C., Sotty, D. and Frindel, E. (1989a). Inhibitor of hematopoietic pluripotent stem cell proliferation: purification and determination of its structure. Proc. Nat. Acad. Sci. USA 86, 779-782.

Lenfant, M., Itoh, K., Sakoda, H., Sotty, D., Sasaki, N. A., WdzieczakBakala, J. and Mori, K. J. (1989b). Enhancement of the adherence of hematopoietic stem cells to mouse bone marrow-derived stromal cell line MS-1-T by a tetrapeptide Acetyl-N-Ser-Asp-Lys-Pro. Exp. Hematol. 17, 898-902.

Li, J., Volkov, L., Comte, L., Hervé, P., Praloran, V. and Charbord, P. (1997). Production and consumption of the tetrapeptide AcSDKP, a negative regulator of hematopoietic stem cells, by hematopoietic microenvironmental cells. Exp. Hematol. 25, 140-146.

Maddocks, S., Hargreave, T. B., Reddie, K., Fraser, H. M., Kerr, J. B. and Sharpe, R. M. (1993). Intratesticular hormone levels and the route of secretion of hormones from the testis of the rat, guinea pig, monkey and human. Int. J. Androl. 16, 272-278

Massé, A., Ramirez, L. H., Bindoula, G., Grillon, C., Wdzieczak-Bakala, J., Raddassi, K., Deschamps de Paillette, E., Mencia-Huerta, J. M., Koscielny, S., Potier, P., Sainteny, F. and Carde, P. (1998). The tetrapeptide Acetyl-Ser-Asp-Lys-Pro (Goralatide) protects from doxorubicin-induced toxicity: improvement in mice survival and protection of bone marrow marrow stem cells and progenitors. Blood $\mathbf{9 1}$, 441-449.

Meinhardt, A., Bacher, M., Metz, C., Bucala, R., Wreford, N., Lan, H., Atkins, R. and Hedger M. (1998). Local regulation of macrophage subsets in the adult rat testis: examination of the roles of the seminiferous tubules, testosterone, and macrophage-migration inhibitory factor. Biol. Reprod. 59, 371-378

Monpezat, J. P. and Frindel, E. (1989). Further studies on the biological activities of the CFU-S inhibitory tetrapeptide AcSDKP. I. The precise point of the cell cycle sensitive to AcSDKP. Studies on the effect of AcSDKP on GM-CFC and the possible involvement of T-lymphocytes in AcSDKP response. Exp. Hematol. 17, 1077-1080.

Morris, I. D., Phillips, D. M. and Bardin, C. W. (1986). Ethylene dimethanesulfonate destroys Leydig cells in the rat testis. Endocrinology 118, 709-719.

Niemi, M., Sharpe, R. M. and Brown, W. R. (1986). Macrophages in the interstitial tissue of the rat testis. Cell Tissue Res. 243, 337-344.

Parvinen, M. and Vanha-Perttula, T. (1972). Identification and enzyme quantitation of the stages of the seminiferous epithelial wave in the rat. Anat. Rec. 174, 435-449.

Parvinen, M., Söder, O., Mali, P., Fröysa, B. and Ritzén, E. M. (1991). In vitro stimulation of stage-specific deoxyribonucleic acid synthesis in rat seminiferous tubule segments by interleukin- $1 \alpha$. Endocrinology 129, 16141620

Pineau, C., Le Magueresse, B., Courtens, J. L. and Jégou, B. (1991). Study in vitro of the phagocytic function of Sertoli cells in the rat. Cell Tissue Res. 264, 589-598.

Ploën, L. and Setchell, B. P. (1992). Blood-testis barriers revisited. An homage to Lennart Nicander. Int. J. Androl. 15, 1-4

Pradelles, P., Frobert, Y., Creminon, C., Liozon, E., Massé, A. and Frindel, E. (1990). Negative regulator of pluripotent hematopoietic stem cell proliferation in human white blood cells and plasma as analysed by enzyme immunoassay. Biochem. Biophys. Res. Commun. 170, 986-993.

Rieger, K. J., Saez-Servent, N., Papet, M. P., Wdzieczak-Bakala, J., Morgat, 
J. L., Thierry, J., Voelter, W., Lenfant, M. (1993). Involvement of human plasma angiotensin I-converting enzyme in the degradation of the haemoregulatory peptide N-acetyl-seryl-aspartyl-lysyl-proline. Biochem. J. 296, 373-378

Roosen-Runge, E. C. (1962). The process of spermatogenesis in mammals. Biol. Rev. 37, 343-377

Rousseau, A., Michaud, A., Chauvet, M. T., Lenfant, M. and Corvol, P. (1995). The hemoregulatory peptide N-Acetyl-Ser-Asp-Lys-Pro is a natural and specific substrate of the N-terminal active site of human angiotensinconverting enzyme. J. Biol. Chem. 270, 3656-3661.

Rousseau-Plasse, A., Wdzieczak-Bakala, J., Lenfant, M., Ezan, E., Genet, R., Robinson, S., Briscoe, T., Melville, J. and Riches, A. (1998). Lisinopril, an angiotensin I-converting enzyme inhibitor, prevents entry of murine hematopoietic stem cells into the cell cycle after irradiation in vivo. Exp. Hematol. 26, 1074-1079

Sharpe, R. (1993). Experimental evidence for Sertoli-germ cell and SertoliLeydig cell interactions. In The Sertoli Cell (ed. L. D. Russell and M. D. Griswold), pp. 391-418. Bolesta Clearwater, USA: Cache River Press.

Sibony, M., Segretain, D. and Gasc, J. M. (1994). Angiotensin-converting enzyme: step-specific expression of the germinal isoform during spermiogenesis. Biol. Reprod. 50, 1015-1026.

Skinner, M. K. and Fritz, I. B. (1985). Testicular peritubular cells secrete a protein under androgen control that modulate Sertoli cell functions. Proc. Nat. Acad. Sci. USA 82, 114-118.

Sotty, D., Lenfant, M., Sasaky, A., Schott, D., Roy, J. and Morgat, J. L. (1991). Radiosynthesis of highly labeled [ $\left.{ }^{3} \mathrm{H}\right]$ Ac-Ser-Asp-Lys-Pro: a natural regulator of hematopoietic system. In Peptides 1990 (ed. E. Giralt and D Andreu), pp. 309-310. Leyden, The Netherlands: ESCOM Science Publishers.

van Rooijen, N. (1989). The liposome-mediated macrophage suicide technique. J. Immunol. Meth. 124, 1-6.

Toppari, J. and Parvinen, M. (1985). In vitro differentiation of rat seminiferous tubular segments from defined stages of the epithelial cycle morphologic and immunolocalization analysis. J. Androl. 6, 334-343.

Watanabe, T., Kelsey, L. S., Yan, Y., Brown, G. S., Jackson, J. D., Ewel, C. and Talmadge, J. E. (1996). In vivo haematoprotective activity of the tetrapeptide AcSDKP combined with granulocyte-colony stimulating factor following sublethal irradiation. Br. J. Haematol. 94, 619-627.

Williams, T. A., Villard, E., Prigent, Y., Dadoune, J. P. and Soubrier, F. (1995). A genetic study of angiotensin I-converting enzyme levels in human semen. Mol. Cell. Endocrinol. 107, 215-219.

Yoshinaga, K., Nishikawa, S., Ogawa, M. Hayashi, S., Kunisada, T., Fujimoto, T. and Nishikawa, S. (1991). Role of c-kit in mouse spermatogenesis: identification of spermatogonia as a specific site of c-kit expression and function. Development 113, 689-699. 